\title{
Of blood, bones, and ribosomes: is Swachman-Diamond syndrome a ribosomopathy?
}

\author{
Arlen W. Johnson ${ }^{1,3}$ and Steve R. Ellis ${ }^{2}$ \\ ${ }^{1}$ Section of Molecular Genetics and Microbiology, The University of Texas at Austin, Austin Texas 78712, USA; ${ }^{2}$ Department of \\ Biochemistry and Molecular Biology, University of Louisville School of Medicine, Louisville, Kentucky 40292, USA
}

\begin{abstract}
Mutations in the human SBDS (Shwachman-Bodian-Diamond syndrome) gene are the most common cause of Shwachman-Diamond syndrome, an inherited bone marrow failure syndrome. In this issue of Genes \& Development, Finch and colleagues (pp. 917-929) establish that SBDS functions in ribosome synthesis by promoting the recycling of eukaryotic initiation factor 6 (eIF6) in a GTPdependent manner. This work supports the idea that a ribosomopathy may underlie this syndrome.
\end{abstract}

Shwachman-Diamond syndrome (SDS) is an inherited bone marrow failure syndrome that is also characterized by exocrine pancreas insufficiency, skeletal abnormalities, and a strong predisposition to myelodysplastic syndrome and acute myelogenous leukemia (Burroughs et al. 2009). While neutropenia is a hallmark of the bone marrow failure in SDS, other hematopoietic lineages are also frequently affected. Approximately $90 \%$ of SDS cases are caused by mutations in the SBDS (ShwachmanBodian-Diamond syndrome) gene (Boocock et al. 2003). These mutations often arise by gene conversion with an adjacent pseudogene. The most common mutations found in SDS patients are thought to be hypomorphic alleles. Mice homozygous for null alleles of $S B D S$ exhibit early embryonic lethality, indicating that $S B D S$ is an essential gene (Zhang et al. 2006). Although structural features of the SBDS protein family suggested early on that these proteins may function in some aspect of RNA metabolism, the exact molecular function of the protein in mammalian cells has been difficult to determine. The Saccharomyces cerevisiae ortholog of SBDS, Sdo1, functions in ribosome biogenesis (Menne et al. 2007; Moore et al. 2010). However, SBDS in mammalian cells has been implicated in multiple pathways, including ribosome biogenesis (Austin et al. 2005), cell motility (Wessels et al. 2006; Leung et al. 2010), reactive oxygen species

[Keywords: bone marrow failure syndromes; ribosome assembly; eIF6; human genetics; leukemia; ribosomopathy; NMR]

${ }^{3}$ Corresponding author.

E-MAIL arlen@mail.utexas.edu; FAX (512) 471-7088.

Article is online at http://www.genesdev.org/cgi/doi/10.1101/gad.2053011. regulation (Ambekar et al. 2010), and stabilizing the mitotic spindle (Austin et al. 2008). This has led to the suggestion that SBDS is a multifunctional protein, which in turn has led to considerable discussion about which, if any, clinical features of SDS are due to defects in ribosome production, and which can be attributed to a role for SBDS in other cellular pathways. The study by Finch et al. (2011) in this issue of Genes \& Development clearly defines a role of SBDS in ribosome synthesis in mammalian cells. This knowledge represents an important step in ongoing efforts to equate clinical features of SDS with cellular processes affected by loss-of-function mutations in SBDS.

In the work described here, Finch et al. (2011) show that SBDS functions in a late step in the cytoplasmic maturation of $60 \mathrm{~S}$ ribosomal subunits. In eukaryotic cells, ribosomes must be shipped from their site of assembly in the nucleus to the cytoplasm, where they function in mRNA translation and protein synthesis. Surprisingly, newly made ribosomes do not arrive at their new job ready to get to work. Instead, they arrive in a functionally inactive form and require some "on-site" unpacking and assembly. Unpacking involves the removal of the small entourage of trans-acting factors that facilitate ribosome assembly and export. Some of these factors also prevent the nascent subunits from engaging prematurely with components of the translation machinery. Yet others act as placeholders for the few ribosomal proteins that are added in the cytoplasm. Perhaps an apt analogy would be taking delivery of a new computer. First, the computer must be removed from its box, which, like export factors, provides the computer with its shipping label. Next, one must remove the tape and plugs-place holders that protect critical ports on the computer. Finally the, peripheral components must be plugged in, akin to adding on specific ribosomal proteins that do not alter the intrinsic function of the machine, but allow it to interface with its user.

A trans-acting factor that keeps the nascent $60 \mathrm{~S}$ subunit in a functionally inactive state is the eukaryotic initiation factor 6 (eIF6; Tif6 in yeast) (Russell and Spremulli 1979). The eIF6 protein binds to an intersubunit bridge (Gartmann et al. 2010) and must be removed before 
the subunit can join a small subunit to initiate translation. The release of Tif6 in yeast requires Sdol (Menne et al. 2007) and the GTPase Efll (Senger et al. 2001), a homolog of the translation translocation factor EF-G. Finch et al. (2011) now provide compelling data that, like Sdo1, SBDS promotes the release of eIF6 from 60S subunits. Moreover, their data reveal that SBDS promotes the release of eIF6 by stimulating the GTPase activity of Efll.

Further insight into the role of SBDS in promoting eIF6 release from 60S subunits was gleaned from the structural studies on SBDS. SBDS is a small three-domain protein, and NMR spectroscopy reveals that its N-terminal domain (domain I) rotates relatively freely in solution with respect to domains II and III. Finch et al. (2011) relate the dynamics of SBDS to the bacterial ribosome-recycling factor (RRF) (Yoshida et al. 2001). RRF works in conjunction with EF-G to promote the dissociation of the 50S and $30 \mathrm{~S}$ subunits and release of the deacylated tRNA (Hirashima and Kaji 1973). RRF binds across the A and P sites of the 50S subunit (Weixlbaumer et al. 2007). During ribosome recycling, a conformational change in EF-G, driven by its GTPase activity, is thought to shift the position of RRF (Savelsbergh et al. 2009), which requires rotation of the head domain. Finch et al. (2011) show that the mutation $\mathrm{K} 151 \mathrm{~N}$, found in some SDS patients, restricted the rotation of domain I. The mutant protein could activate Efll GTPase activity, but could not support the release of eIF6. Thus, this mutation appears to uncouple the GTPase activity of Efll from its function in promoting eIF6 release. In other words, wild-type SBDS protein couples the GTPase activity of Efl1 with eIF6 release. Considering that Efl1 is related to EF-G, and that SBDS displays similarities to bacterial RRF, it seems reasonable to suggest that SBDS, together with Efll, may in some fashion replicate bacterial ribosome recycling, but in the context of ribosome maturation. Indeed, both pathways generate free ribosomal subunits. Archaea contain orthologs of eIF6 and SBDS but not Efl1, leading one to suspect that archaeal EF-G promotes both translocation and release of archaeal eIF6 in an Sdo1-dependent fashion. Thus, ribosome recycling and 605 biogenesis may be related in ways we have not considered previously.

While these results from the Warren laboratory (Finch et al. 2011) clearly establish a role for SBDS in promoting eIF6 release from 60S subunits, they do not settle the question of whether the defect in ribosome synthesis is responsible for some or all of the clinical features of SDS. The mouse model presented in this study is a liverspecific conditional deletion of exon 2 of $S B D S$, which, when homozygous, results in a complete loss of functional protein. A homozygous deletion of exon 2 in the whole mouse is embryonic-lethal, and therefore does not recapitulate the clinical features observed in Shwachman-Diamond patients. Thus, it is unclear to what degree the effects of the conditional knockout on liver pathology reflect the transient changes in liver function observed in SDS patients (Toiviainen-Salo et al. 2009). In yeast, the defects of $s d o 1$ mutants are suppressed by mutations in
TIF6 that weaken the affinity of Tif6 for the ribosome, allowing it to be released without the need for Sdo1 (Menne et al. 2007). To more conclusively establish a role for SBDS in eIF6 recycling as the basis for phenotypic effects in mammalian cells, it would be of great interest to determine whether mutations in eIF6 could rescue these disease phenotypes, as tif 6 mutations rescue the growth defects of sdo1 mutants in yeast.

Previous studies on the release of eIF6 from 60S subunits in mammalian cells have suggested a role for RACK1 and protein kinase $\mathrm{C}$ in regulating eIF6 release through phosphorylation (Ceci et al. 2003). Finch et al. (2011) address whether eIF6 phosphorylation is required for eIF6 release in their system and conclude that it is not. Using a C-terminally truncated form of eIF6 that lacks Ser 235, the putative target of phosphorylation, they show that Efll and SBDS are sufficient for the release of this protein from ribosomes in vitro. They also report that they were unable to detect phosphorylation of Ser 235 despite being able to identify other phosphorylated residues. However, one cannot rule out the possibility that the C-terminal truncation removes a domain that makes phosphorylation of Ser 235 essential for release. Consequently, this debate will continue to simmer until similar experiments are done with point mutants that specifically alter the putative phosphorylation target.

In summary, the study by Finch et al. (2011) presented here clearly documents a role for SBDS in the maturation of $60 \mathrm{~S}$ subunits in mammalian cells. Further understanding of this and the myriad other potential functions reported for this fascinating protein should ultimately pinpoint the biochemical defects underlying the tissue selectivity and cancer predisposition observed in the clinical presentation of SDS.

\section{Acknowledgments}

A.W.J. was supported by NIH GM53622, and S.R.E. was supported by the Swachman Diamond Project.

\section{References}

Ambekar C, Das B, Yeger H, Dror Y. 2010. SBDS-deficiency results in deregulation of reactive oxygen species leading to increased cell death and decreased cell growth. Pediatr Blood Cancer 55: 1138-1144.

Austin KM, Leary RJ, Shimamura A. 2005. The ShwachmanDiamond SBDS protein localizes to the nucleolus. Blood 106: 1253-1258.

Austin KM, Gupta ML, Coats SA, Tulpule A, Mostoslavsky G, Balazs AB, Mulligan RC, Daley G, Pellman D, Shimamura A. 2008. Mitotic spindle destabilization and genomic instability in Shwachman-Diamond syndrome. J Clin Invest 118: 15111518.

Boocock GR, Morrison JA, Popovic M, Richards N, Ellis L, Durie PR, Rommens JM. 2003. Mutations in SBDS are associated with Shwachman-Diamond syndrome. Nat Genet 33: 97-101.

Burroughs L, Woolfrey A, Shimamura A. 2009. ShwachmanDiamond syndrome: a review of the clinical presentation, molecular pathogenesis, diagnosis, and treatment. Hematol Oncol Clin North Am 23: 233-248.

Ceci M, Gaviraghi C, Gorrini C, Sala LA, Offenhauser N, Marchisio PC, Biffo S. 2003. Release of eIF6 (p27BBP) from 
the 60 S subunit allows 80 S ribosome assembly. Nature 426: 579-584.

Finch AJ, Hilcenko C, Basse N, Drynan LF, Goyenechea B, Menne TF, González Fernández A, Simpson P, D'Santos CS, Arends MJ, et al. 2011. Uncoupling of GTP hydrolysis from eIF6 release on the ribosome causes Shwachman-Diamond syndrome. Genes Dev (this issue). doi: 10.1101/gad.623011.

Gartmann M, Blau M, Armache JP, Mielke T, Topf M, Beckmann R. 2010. Mechanism of eIF6-mediated inhibition of ribosomal subunit joining. J Biol Chem 285: 14848-14851.

Hirashima A, Kaji A. 1973. Role of elongation factor G and a protein factor on the release of ribosomes from messenger ribonucleic acid. I Biol Chem 248: 7580-7587.

Leung R, Cuddy K, Wang Y, Rommens J, Glogauer M. 2010.Sbds is required for Rac2-mediated monocyte migration and signaling downstream of RANK during osteoclastogenesis. Blood 117: 2044-2053.

Menne TF, Goyenechea B, Sanchez-Puig N, Wong CC, Tonkin LM, Ancliff PJ, Brost RL, Costanzo M, Boone C, Warren AJ. 2007. The Shwachman-Bodian-Diamond syndrome protein mediates translational activation of ribosomes in yeast. Nat Genet 39: 486-495.

Moore JB IV, Farrar JE, Arceci RJ, Liu JM, Ellis SR. 2010. Distinct ribosome maturation defects in yeast models of DiamondBlackfan anemia and Shwachman-Diamond syndrome. Haematologica 95: 57-64.

Russell DW, Spremulli LL. 1979. Purification and characterization of a ribosome dissociation factor (eukaryotic initiation factor 6) from wheat germ. J Biol Chem 254: 8796-8800.

Savelsbergh A, Rodnina MV, Wintermeyer W. 2009. Distinct functions of elongation factor $\mathrm{G}$ in ribosome recycling and translocation. RNA 15: 772-780.

Senger B, Lafontaine DL, Graindorge JS, Gadal O, Camasses A, Sanni A, Garnier JM, Breitenbach M, Hurt E, Fasiolo F. 2001. The nucle/ol/ar Tif6p and Efllp are required for a late cytoplasmic step of ribosome synthesis. Mol Cell 8: 1363 1373.

Toiviainen-Salo S, Durie PR, Numminen K, Heikkila P, Marttinen E, Savilahti E, Makitie O. 2009. The natural history of Shwachman-Diamond syndrome-associated liver disease from childhood to adulthood. J Pediatr 155: 807-811 e802.

Weixlbaumer A, Petry S, Dunham CM, Selmer M, Kelley AC, Ramakrishnan V. 2007. Crystal structure of the ribosome recycling factor bound to the ribosome. Nat Struct Mol Biol 14: 733-737.

Wessels D, Srikantha T, Yi S, Kuhl S, Aravind L, Soll DR. 2006. The Shwachman-Bodian-Diamond syndrome gene encodes an RNA-binding protein that localizes to the pseudopod of Dictyostelium amoebae during chemotaxis. I Cell Sci 119: 370-379.

Yoshida T, Uchiyama S, Nakano $\mathrm{H}$, Kashimori $\mathrm{H}$, Kijima $\mathrm{H}_{\text {, }}$ Ohshima T, Saihara Y, Ishino T, Shimahara H, Yokose K, et al. 2001. Solution structure of the ribosome recycling factor from Aquifex aeolicus. Biochemistry 40: 2387-2396.

Zhang S, Shi M, Hui CC, Rommens JM. 2006. Loss of the mouse ortholog of the shwachman-diamond syndrome gene (Sbds) results in early embryonic lethality. Mol Cell Biol 26: 66566663. 


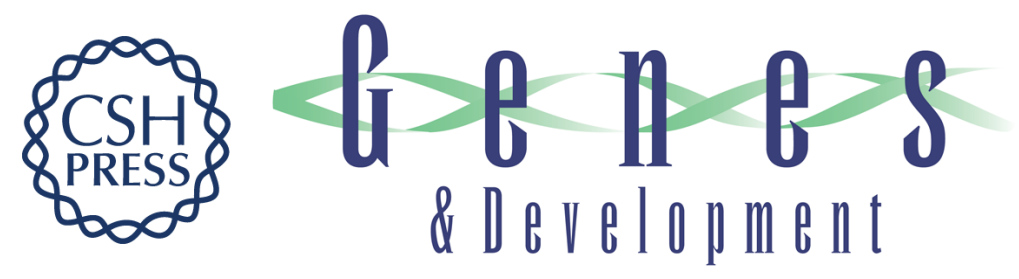

\section{Of blood, bones, and ribosomes: is Swachman-Diamond syndrome a ribosomopathy?}

Arlen W. Johnson and Steve R. Ellis

Genes Dev. 2011, 25:

Access the most recent version at doi:10.1101/gad.2053011
Related Content Uncoupling of GTP hydrolysis from elF6 release on the ribosome causes Shwachman-Diamond syndrome
Andrew J. Finch, Christine Hilcenko, Nicolas Basse, et al.
Genes Dev. May , 2011 25: 917-929
References This article cites 19 articles, 8 of which can be accessed free at:
http://genesdev.cshlp.org/content/25/9/898.full.html\#ref-list-1
Articles cited in:
http://genesdev.cshlp.org/content/25/9/898.full.html\#related-urls

\section{License}
Email Alerting
Receive free email alerts when new articles cite this article - sign up in the box at the top Service

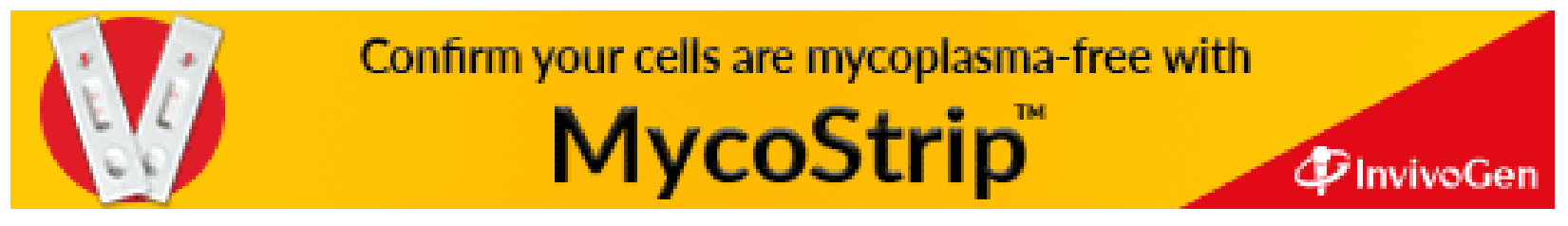

